Journal of Southeast Asian Studies, 48(3), pp 372-389 October 2017.

(c) The National University of Singapore, 2017 doi:10.1017/S0022463417000546

\title{
Flights of fancy: The bird of paradise and its cultural impact
}

\author{
Leonard Y. Andaya
}

\begin{abstract}
The aim of this essay is to show through just one greatly valued trade item - in this case, the bird of paradise - how even the most distant and apparently isolated areas of the world could be linked to the major metropoles through trade. Yet this trade was anything but a simple bilateral exchange. It involved a complex series of networks that extended from the collectors to various levels of intermediaries and secondary ports, and then to foreign shippers bringing the desired product to its ultimate destination in various world markets. There is, however, another aspect of this essay which focuses not on the economic but the cultural value of trade. Most studies of the bird of paradise have commented on the cultural impact of its feathers on Western fashion, yet few have examined other cultural interpretations of the feathers that are closely associated with authority, fertility, and even invulnerability. These attitudes found in eastern Indonesia and New Guinea continue a tradition that has its roots in Southeast Asia in the early centuries of the Common Era.
\end{abstract}

Southeast Asia has long been known for its exotic fauna and flora that have supplied royal courts and elite households around the world. Its seas and jungles produced such items as kingfisher's feathers, rhinoceros horns, edible birds' nests, sea cucumbers, and even the concretions (guliga; bezoars) in the bodies of native monkeys and porcupines. Amidst the array of unique and wondrous objects from Southeast Asia, none aroused as much curiosity and myth-making as the appropriately named 'birds of paradise'. So stunning was their plumage that Creationists in the late nineteenth century, rejecting Darwin's and Wallace's ideas of evolution, used these creatures as irrefutable evidence of God's work. ${ }^{1}$ The sheer beauty of their feathers, the unusual manner in which they were packed for export, and the absence of any reliable eyewitness accounts of where they nested and how they reared their young all contributed to the mystery that surrounded these birds. Even in the twenty-first century a BBC crew accompanying some native New Guinean environmentalists were able to film some magnificent mating dances of a variety of birds

Leonard Y. Andaya is Professor of Southeast Asian History, at the University of Hawaici at Manoa. Correspondence in connection with this article should be addressed to: andaya@hawaii.edu. All maps (C) Leonard Y. Andaya.

1 David Quammen, The song of the Dodo: Island biogeography in an age of extinctions (New York: Scribner, 1996), p. 610. 


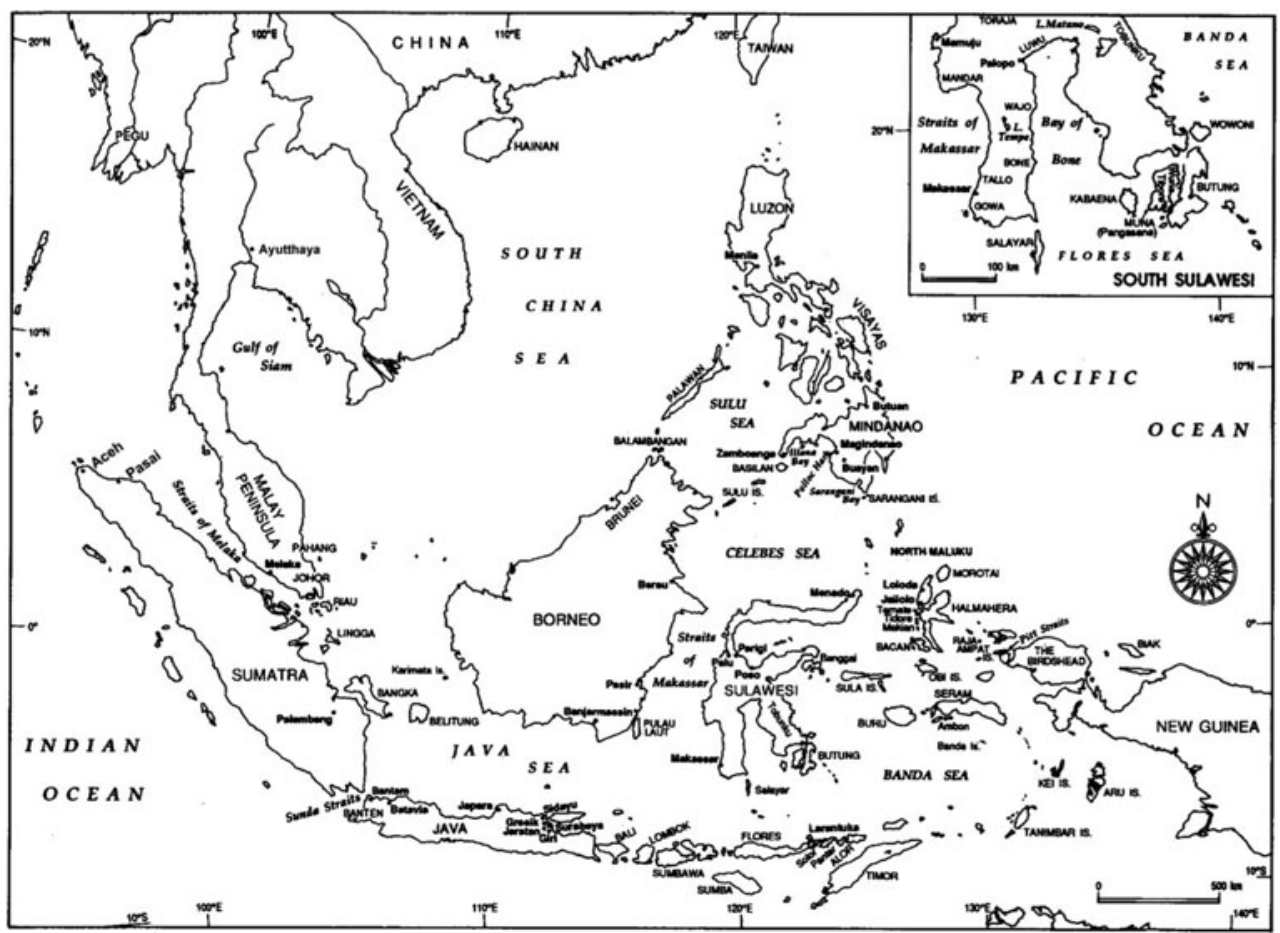

\section{Map 1: Island World Southeast Asia}

of paradise, but remained unenlightened on their other habits. ${ }^{2}$ In the past the combination of the magnificence of their feathers and the mystery that surrounded their habits and habitats increased the demand for these birds. The demand was not simply for their spectacular plumage, but also because for many indigenous groups the 'bird of the gods' contained special powers that could be harnessed for the good of the population.

In this essay I begin by examining the variety of birds of paradise and their general habitat in the islands of eastern Indonesia and the large island of New Guinea. I then turn to the history of the trade in these birds and the earliest evidence we have of their presence in such distant places as China, India, the Middle East, and Europe. The intricate trading arrangements which brought the bird of paradise feathers to the global market are discussed to demonstrate the great effort that was necessary to bring the feathers and other eastern Indonesian and New Guinean products to the outside world. Then I examine the various uses of bird of paradise feathers as ornaments to adorn the helmets of European medieval knights and the headdresses of Papuans in New Guinea and the Aru and Tanimbar islanders of eastern Indonesia; as high fashion among Western women; and as items of particular value to grace the crowns of the rulers and high officials of the Himalayan kingdom of Nepal. Finally, I turn to the significance of the feathers of the birds of paradise to the Papuans themselves up to the present day.

2 David Attenborough (narrator) and BBC, Natural world: Birds of paradise, 60 mins, BBC TV, 2010. 
The aim of this essay is to show through just one greatly valued item - the bird of paradise - how trade could link even the most distant and apparently isolated areas of the world to the major metropoles. Yet this trade was anything but a simple bilateral exchange. It involved a complex series of networks that extended from the collectors to various levels of intermediaries and secondary ports, and then to foreign shippers bringing the desired product to its ultimate destination in various world markets. There is, however, another aspect of this essay which focuses not on the economic but the cultural value of the item to certain indigenous societies in eastern Indonesia and New Guinea. Historians have generally privileged the economic aspects of trade and left unexplored the cultural impact of such trade. Almost all the studies of the bird of paradise have commented on the cultural impact of its feathers on Western fashion, with only a rare few focusing on a deeper significance. Yet, as this essay argues, among certain indigenous societies the bird of paradise is appropriately known as the 'bird of God', which accurately captures its important function in assuring the fecundity of the land and people and thus guaranteeing the well-being of the community.

\section{'Birds of God'}

The first recorded specimens of the bird of paradise were those brought back to Spain by Magellan's crew in 1522. According to Antonio Pigafetta, the Italian chronicler of Magellan's expedition, the ruler of the kingdom of Bacan (northern Maluku in eastern Indonesia) gave the captain a gift of birds of paradise, which were to be presented to the king of Spain. Pigafetta describes the gift of

two very beautiful dead birds, which are as thick as stock-doves, with small head and long beak, and legs a palm in length and as thin as a feather. They have no wings, but have instead long feathers of divers colors like large plumes. The tail is as long as that of a stock-dove, and all the other feathers except the wings are of a tawny color, and they never fly except when there is wind. We were told that those birds came from the earthly paradise and were called Bolon diuata [burung dewata], that is to say, birds of God. ${ }^{3}$

This is a description of the Lesser Bird of Paradise (Paradisaea minor), and what is noteworthy is that Pigafetta specifically mentions that the feet were intact, and that they were called by the natives 'birds of God'. ${ }^{4}$ Toward the end of the sixteenth century, these remarkable creatures were called by a variety of names: manuk dewata (Maluku, 'birds of God'), passaros de sol (Port., 'birds of the sun'), Avis paradiseus (Latin, 'birds of paradise'). Throughout the region the birds were generally known by Malay traders as burung mati (dead birds) because they never saw the birds alive. Later commentators speculated that these birds were called 'birds of God' because they were usually sold without their feet, giving rise to the myth that they flew in the air and never alighted until they died and fell to earth. In his

3 Antonio Pigafetta, Magellan's voyage: A narrative account of the first circumnavigation, vol. 1, ed. R.A. Skelton (New Haven: Yale University Press, 1969), p. 126.

4 This is a Malay term, but the word translated as 'God' is derived from the Sanskrit dewa. This indicates that the people that Magellan's crew spoke to were most likely non-Muslims. 
tongue-in-cheek response to these wild speculations, Carl Linnaeus, the famous eighteenth-century Swedish botanist and zoologist, gave the Greater Bird of Paradise the name Paradisaea apoda or 'the Feetless Bird of Paradise'. ${ }^{5}$ A painting completed around 1617 by Bruegel the Elder and Rubens, Adam and Eve in Paradise, depicts the bird of paradise with feet, but it was not till sometime in 1823-24 that a European finally described a live bird in its natural habitat. ${ }^{6}$

In the mid-sixteenth century a well-known mathematician and medical doctor, Geronymo Cardano, had pronounced on the lifestyle of the birds of paradise, claiming that without feet they float effortlessly through the air and subsist on heavenly dew. The eggs, he said, are laid in a unique cavity found in the back of the male bird, from which springs the young. These special creatures are thus able to live entirely in the air without ever descending to earth even for breeding. A Catholic bishop in 1597 even viewed the bird of paradise as a metaphor for sinners who, falling from God's grace, plummet to earth. ${ }^{7}$ Among the Papuans was a belief that when the birds were near death, they flew directly toward the sun until exhausted, then fell down to earth and died. ${ }^{8}$ The feathers of the bird of paradise were used as ornamentation by the Spaniards, and by the 1540s many were found in the major European cultural centres and graced many a curiosity cabinet. ${ }^{9}$ The Chinese, too, were fascinated by these wondrous creatures and included them in their catalogues of exotic birds. $^{10}$

Bird of paradise feathers were known in China as far back as the eighth century, and the plumes had also found their way to India and the Arab world. Medieval knights in Europe in the thirteenth century were said to have worn the feathers in their helmets, ${ }^{11}$ though the provenance of the feathers is not known and may have come via the Arab world. The scarcity and beauty of these feathers made them objects of great value, and hence they were found primarily in the courts of Europe and in the households of the rich and powerful. Within Southeast Asia itself, the feathers continue to be greatly prized among the Papuans and the Malukans of eastern Indonesia for their splendour and the belief in their spiritual potency. In reaffirming an alliance between villages in Tanimbar, for instance, both men and women don their finest cloths and ornaments, which includes for the women a headdress consisting of the tail feathers of the bird of paradise, and for the men a headdress that is said to represent the bird's crest. ${ }^{12}$

5 Alfred Russel Wallace, The Malay archipelago, vol. 2 (London: Macmillan \& Co., 1869), pp. 387-8.

6 Clive Moore, New Guinea: Crossing boundaries and history (Honolulu: University of Hawai'i Press, 2003), pp. 113-14.

7 Erwin Stresemann, 'Die entdeckungsgeschichte der paradiesvogel', Journal für Ornithologie 95 (1954): 265, 267.

8 François Valentijn, Oud en nieuw Oost-Indiën, 'Beschryving der Moluccos', vol. 3, bk. 1 (Dordrecht/Amsterdam: Joannes van Braam, Gerard Onder de Linden, 1724), p. 311.

9 Stresemann, 'Die entdeckungsgeschichte': 264-5.

10 Roderich Ptak, Exotische vögel: Chinesische beschreibungen und importe (Wiesbaden: Harrassowitz, 2006), pp. 91-9.

11 Jean Gelman Taylor, Indonesia: Peoples and histories (New Haven: Yale University Press, 2003), p. 55 .

12 Susan McKinnon, 'The coolness of peace, the heat of the contest: Intervillage alliances in the Tanimbar Islands', in Maluku and Irian Jaya, ed. E.K.M. Masinambow (Jakarta: Leknas, LIPI, 1984), p. 297. 
Western demand for bird of paradise feathers reached a peak in the first two decades of the twentieth century, when hats with bright-coloured plumes became high fashion in Europe and the United States. There was a dramatic increase in the numbers of birds of paradise that were killed to satisfy this demand. From 1905 to 1920, between 30,000 to 80,000 birds were killed annually and exported to feather auctions in London, Paris, and Amsterdam. ${ }^{13}$ All efforts to limit the trade in order to prevent the extinction of the bird of paradise were unsuccessful, and only a change in fashion ended this wide-scale slaughter. ${ }^{14}$ Fortunately, the danger of extinction has lessened because of a shift in the fickle fashion world and the increasingly vigorous preservation efforts in more recent times.

\section{Birds of paradise and their habitats}

There are forty-two known species of birds of paradise, of which thirty-eight are found in New Guinea, two in Australia, and two in Maluku in eastern Indonesia. ${ }^{15}$ The climate in New Guinea is generally wet, though it is possible to distinguish between a 'dry season' from May to November, and a 'wet season' from October to April. Most of the native birds, including the birds of paradise, reach a peak of plumage display during the dry season and the beginning of the wet season, which marks the height of the nesting period. ${ }^{16}$ G.E. Rumphius, the Belgian naturalist in the employ of the Dutch East India Company (VOC) in the seventeenth century, was the first to document six species of the bird. Though the original manuscript is lost, his observations are repeated in François Valentijn's monumental study, Oud en Nieuw Oost-Indien, published in 1724. Among the six species mentioned are the Lesser Bird of Paradise, which were the birds brought back to Europe by Magellan's crew, and the Greater Bird of Paradise (which Linnaeus named the 'Feetless Bird of Paradise', to mock prevalent European views). The former species is found near the coast in the Bird's Head Peninsula of West Papua Province and in the Jayapura region of Papua Province in Indonesia, while the latter is located in southwest Papua New Guinea as well as in the Trans Fly region which straddles both countries. ${ }^{17}$

While in Aru, Alfred Russel Wallace witnessed the mating dance of the Greater Bird of Paradise, although its habitat is in New Guinea. Some of these birds fly to the nearby Aru Islands during the mating season, though such a journey can be treacherous because of the peculiar nature of their feathers. He noted that in September and October the silky feathers of the birds were in full perfection. It was then that they

13 Stuart Kirsch, 'History and the birds of paradise: Surprising connections from New Guinea', Expeditions 49, 1 (2006): 16.

14 Robert Cribb provides a useful study of mainly futile efforts to curb the trade to prevent the bird's extinction. By the time the Dutch passed the 'Animal Protection Ordinance' in 1931, fashion trends using exotic bird feathers had already passed. Robert Cribb, 'Birds of paradise and environmental politics in colonial Indonesia, 1890-1931', in Paper landscapes: Explorations in the environmental history of Indonesia, ed. Peter Boomgaard et al. (Leiden: KITLV, 1997), p. 403.

15 Pamela Swadling, Plumes from paradise: Trade cycles in outer Southeast Asia and their impact on New Guinea and nearby islands until 1920 (Boroko: Papua New Guinea National Museum; Robert Brown \& Associates, 1996), p. 49.

16 E. Thomas Gilliard, Birds of paradise and bower birds (London: Weidenfeld \& Nicolson, 1969), p. 5. 17 Swadling has provided an excellent map showing where the different species of the birds of paradise are found in New Guinea. Swadling, Plumes, pp. 68-9. 


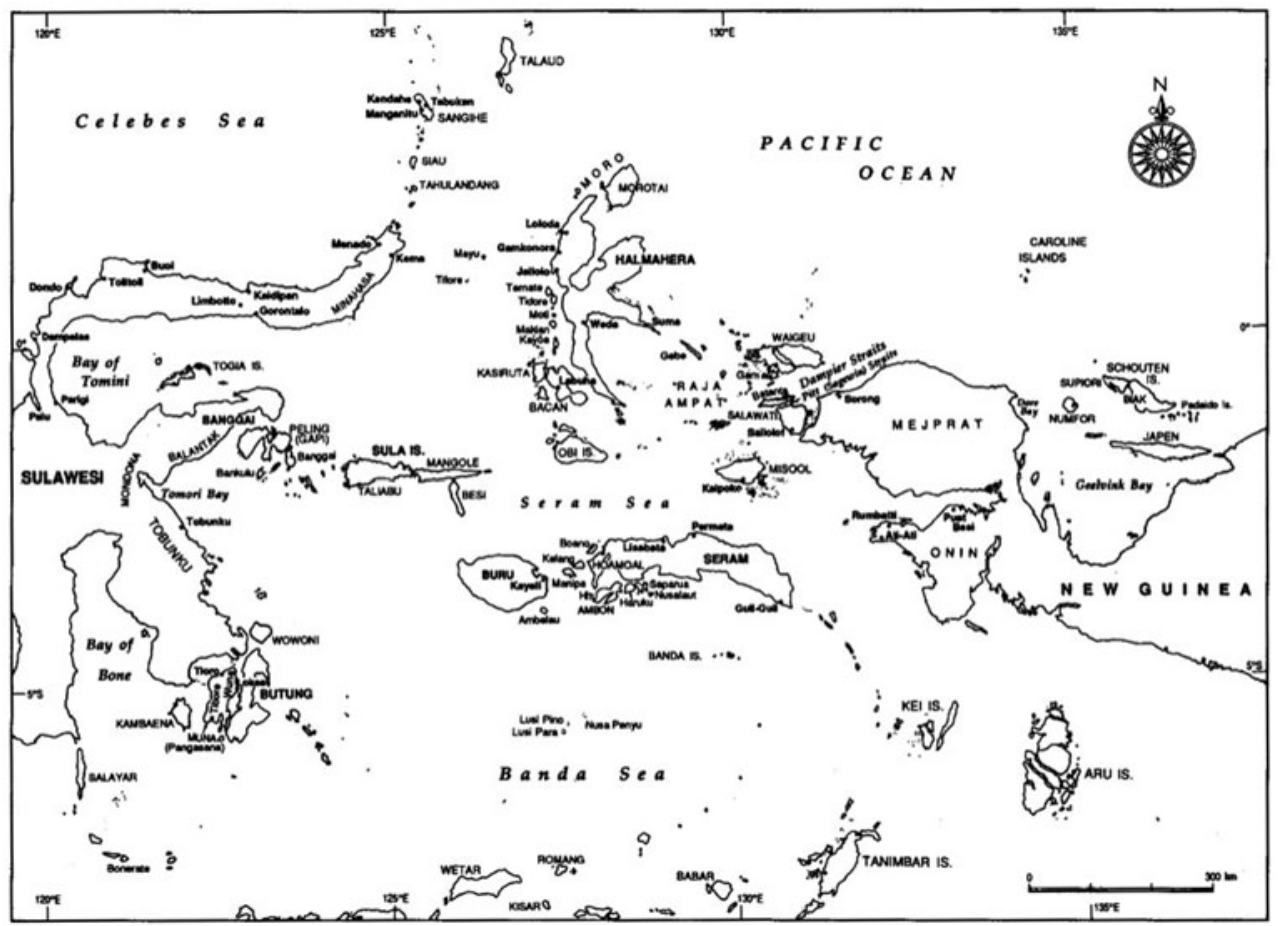

Map 2: Maluku and New Guinea

began their special mating dance on very large trees with extensive canopies but scattered foliage, allowing a space for the birds to strut in the sun to display their splendid feathers. In one tree he saw assembled between a dozen and twenty male birds in full plumage, raising their wings and stretching their necks all the while maintaining a continuous vibration which contributed to the brilliance of the display of the plumes. Flying from branch to branch, the birds presented a spectacle of colourful feathers in constant motion in all manner of poses. Wallace writes:

The bird itself is nearly as large as a crow, and is of a rich coffee brown colour. The head and neck is of a purest yellow above, and rich metallic green beneath. The long plumy tufts of golden orange feathers spring from the sides beneath each wing, and when the bird is in repose are partly concealed by them. At the time of its excitement, however, the wings are raised vertically over the back, the head is bent down and stretched out, and the long plumes are raised up and expanded till they form two magnificent golden fans, striped with deep red at the base, and fading off into the pale brown tint of the finely divided and softly waving points. The whole bird is then overshadowed by them, the crouching body, yellow head, and emerald green throat forming but the foundation and setting to the golden glory which waves above. When seen in this attitude, the Bird of Paradise really deserves its name, and must be ranked as one of the most beautiful and most wonderful of living things. ${ }^{18}$

Wallace, Malay Archipelago, vol. 2, pp. 252-3. 
Among the Papuans of New Guinea and neighbouring islands, the species that is most prized is the Raggiana Bird of Paradise (Paradisaea raggiana; cenderawasih in Indonesian), which appears in the national crest and the flag of Papua New Guinea. ${ }^{19}$ They are found in southern and northeastern Papua New Guinea, and their feathers adorn the headdress of many Papuan dancers during special festivals. In Indonesia's Papua Province, the cenderawasih's popularity is reflected in the fact that its name has been given to a bay, a university, and to streets.

\section{Hunting and packing the birds of paradise}

The hunting of the birds of paradise occurs during the mating season, which is in the dry season between May and November. One of the earliest descriptions is found in a 1599 report by the VOC Vice-Admiral Jacobs Heemskerk. He cites the account of an Ambonese captain who was told of the habits of the birds of paradise by traders at Seram Laut, a principal market for New Guinea goods. According to this captain, the birds fly in large flocks, and when they want to stop to drink, they first send a scout to the source of water. If that bird drinks and returns safely, then the others follow suit. The natives, therefore, immediately poison the water hole and wait in hiding for the coming of the whole flock. Once they drink the water, they are drugged and are easily shot and captured by the hunters. ${ }^{20}$ Rumphius identifies the species as the 'Small or Papuan Bird of Paradise' and provides a few more details:

The Papuans report that when they're flying in a flock and see some water hole or water, one of the flock goes down to see whether it is good, then reports back, before the fleet goes down to drink. The Papuans knowing that, will wait till the bird returns to report back to the flock that all is well, then they drug the water with Bori of the Cocculi Indici. Then they capture the whole flock. Though they could easily catch them alive, they prefer to kill them. ${ }^{21}$

The reason that only a single bird scouts out the water may be explained by an observation made in the late eighteenth century by Thomas Forrest during his voyage to New Guinea. He noted that, because of the length and structure of the bird's scapular feathers, once they land they find it difficult to be airborne again, making them vulnerable to hunters. In periods of high winds, these feathers also hinder their settling on large trees. They are unable to fly with the wind because of their loose plumage, and thus must fly against the wind, a dangerous endeavour during strong winds. If they fall to the ground and are captured, they are immediately killed because 'they defend themselves with amazing courage and formidable bills' ${ }^{22}$

Killing the birds while on their annual flight to their mating grounds, however, is not the primary way in which they are hunted. The most successful hunters locate the

19 After having viewed this species in New Guinea's west coast in 1873, the Italian explorer and naturalist Luigi D'Albertis named it after his friend, the Marquis Raggi of Genoa. Kirsch, 'History and the birds of paradise': 18 .

20 Stresemann, 'Die entdeckungsgeschichte': 268-9.

21 Valentijn, Oud en nieuw, vol. 3, bk. 1, p. 311. Valentijn had used Rumphius's work in recounting this peculiarity of the bird of paradise, but that work has now been lost.

22 Thomas Forrest, A voyage to New Guinea and the Moluccas from Balambangan (London: G. Scott, 1779), pp. 135-6. 
sites where the mating occurs, which are often places that the birds return to every year. When the males begin their dance, the brilliant feathers are displayed for the benefit of the female birds watching from the surrounding trees. It is then that the birds are most vulnerable and fall victim to the hunters cleverly camouflaged in the trees who can then shoot the male birds at will (see Figure 1). The fact that many of the birds mate at specific trees or clearings on the ground every year has made them easy prey. Yet even after learning the mating habits of the various species of birds of paradise and their favourite areas for their special mating dance, the hunters still need extreme patience and skill to catch these birds. ${ }^{23}$

Wallace was the first naturalist to have witnessed and described the mating dance of the Greater Bird of Paradise in 1857, which accorded with the earliest European report in $1680 .{ }^{24}$ The natives termed the mating dance 'cakalele', the local term for a war dance. ${ }^{25}$ Forrest noted that the birds of paradise tended to select the highest trees, especially the small-leafed waringin tree, to feed on its berries. The natives thus used bird lime, nooses, and blunt arrows to kill them when they alighted on these special trees. ${ }^{26}$ A Dutch official in the early twentieth century witnessed the same phenomenon in which some thirty male birds descended on a large tree. He describes how the male birds took flight at each shot, but later again returned. The hunters simply spent several days at the site of the tree and were eventually able to shoot down all the male birds. While travelling along the south coast of MacCluer Gulf (Teluk Berau) in the Onin Peninsula of New Guinea, that same official observed a custom among the Baham people regarding the hunting of the birds of paradise. If a person discovered a 'mating tree', he could claim it as his own, and no other hunter would hunt on that tree unless he purchased that right from the owner. At such trees it was not uncommon to have thirty or more birds, both male and female, gathered in the morning and at midday. ${ }^{27}$

In a more recent description of the hunt for the red-plumed Raggiana in the southern watershed valleys of eastern Papua New Guinea, a museum naturalist describes the special ownership exercised by the local population over individual male birds and on the trees that they inhabit for their dance. These claims are respected because it is often the owner who discovered the bird and its special mating site, and it is he who keeps a close watch over them. Hence the entire valley consists of such claimed trees and birds, requiring permission from the owners to take the birds. These Raggiana birds of paradise perform their mating dance on immense trees that rise high above the surrounding jungle. The trees tend to be bare-limbed, thus exposed to the sunshine. When the males descend upon the branches of this special tree, the female birds begin to gather on the surrounding trees to watch the special

23 William Fisher Alder, The isle of vanishing men: A narrative of adventure in cannibal-land (New York: Century, 1922), pp. 170-71.

24 Gilliard, Birds of paradise, p. 216.

25 David Attenborough and the BBC produced a wonderful and informative documentary on the birds of paradise and have recorded magnificent footage on the birds and their various splendid and peculiar mating dances. Attenborough and BBC, Birds of paradise.

26 Forrest, Voyage, p. 134; Swadling reports that they are known as 'dancing trees'. Plumes, p. 182.

27 J.S.A. van Dissel, 'Reis van Goras langs de Bedidi naar Ginaroe, en over Womera weer naar Goras (vierde voetreis in het bergland van z.s. Nieuw-Guinea)', Tijdschrift van het Aardrijkskundig Genootschap 24, 2 (1907): 1016-17. 


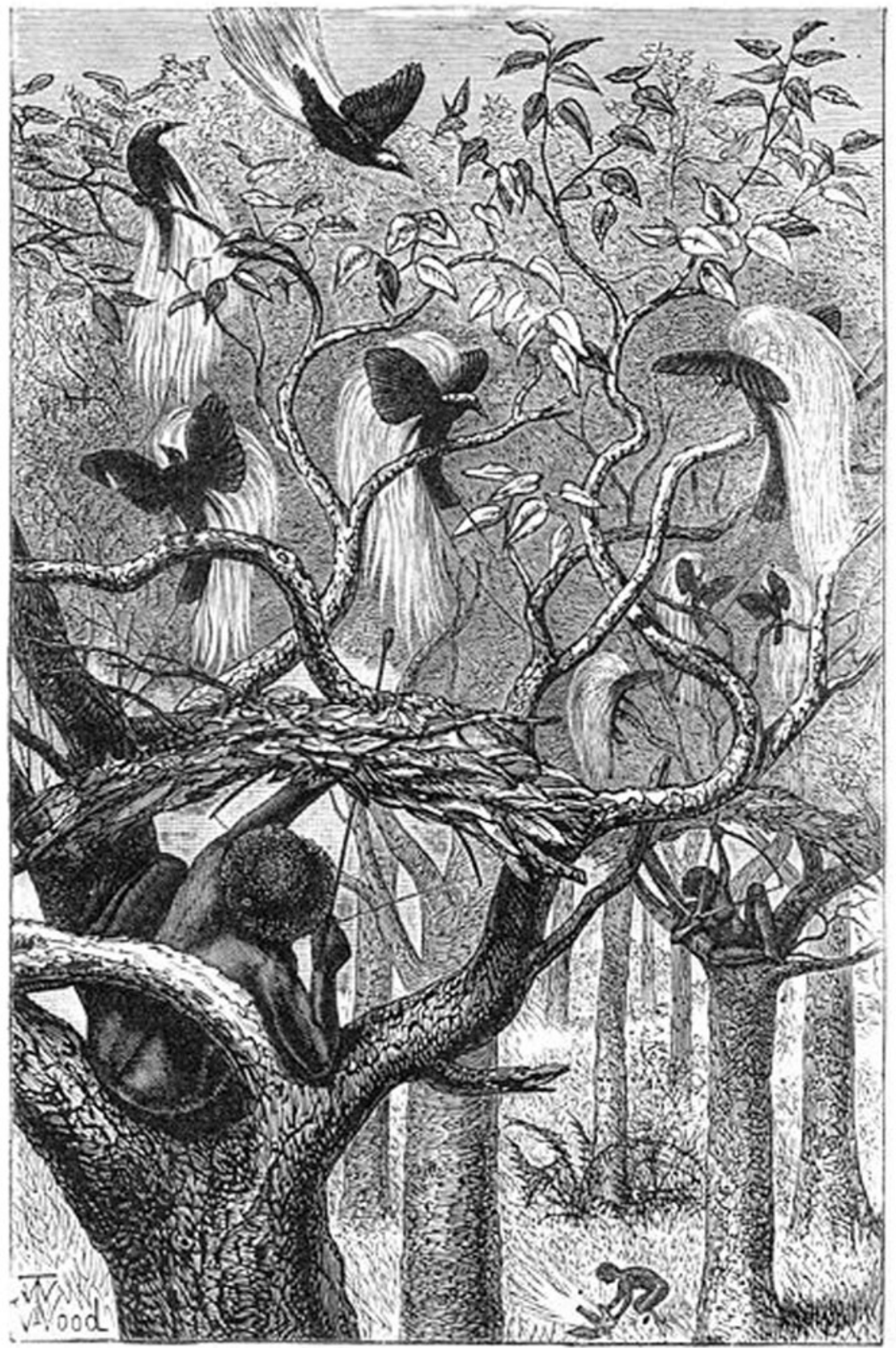

Figure 1. Hunting Birds of Paradise. Males of the Greater Bird of Paradise species gathered in lofty trees with exposed branches where they could dance and display their feathers to attract watching females. Hunters hid under a canopy of leaves and fired blunt arrows so that they did not damage the beautiful plumage. Alfred Russel Wallace, The Malay Archipelago (New York: Harper \& Brothers, 1869), frontispiece. Courtesy of the John M. Echols Collection on Southeast Asia of Cornell University Library. 
dance. Hunters who are camouflaged in their special hunting perches then are able to kill about two-thirds of the male birds before they finally take notice and disperse. ${ }^{28}$

Once the birds are killed, they are immediately degutted, the skull, feet, and wings removed, a rod passed through the body, and then either set out in the sun or smoked to dry the feathered carcass. The so-called 'skins' are then placed in a bamboo tube, and in a case noted by François Valentijn in the late seventeenth century, camphor was added periodically to the bamboo to preserve the skin, which could then be brought unspoiled to Europe. ${ }^{29}$ Another method of preparing the skin is by smoking, which Wallace in the late nineteenth century observed in Aru where the hunters

cut off the wings and feet, and then skin the body up to the beak, taking out the skull. A stout stick is then run up through the specimen coming out at the mouth. Round this some leaves are stuffed, and the whole is wrapped up in a palm spathe and dried in the smoky hut. By this plan the head, which is really large, is shrunk up almost to nothing, the body is much reduced and shortened, and the greatest prominence is given to the flowing plumage. ${ }^{30}$

His comments accord with the observation made by a Dutchman earlier in that century regarding the smoking process used by the indigenous hunters from one of the Aru Islands. ${ }^{31}$ In the beginning of the twentieth century an American described the preparation, which may have been the end process of one of the earlier two methods discussed above:

The skins, as they are gathered, are washed in arsenic soap and packed away in bundles of twenty. The washing shrinks a skin so that the true proportions of the bird are lost: the head is large in relation to the rest of the body, but with the removal of the skull it shrinks to such an extent that it seems to be exceedingly small. The skin is taken for the gorgeous plumes which spring from the side of the bird and are best seen on the live bird when he is strutting or in flight. ${ }^{32}$

In the preparation for export to the outside world, packaging the birds so that they could be easily transported without damaging the feathers was of major concern. But for the Papuan market, the birds were prepared with two principal considerations in mind: the first was to make it easy to mount the bird skins with their brilliant plumage as part of a headdress for special festivals; and the second was to facilitate storage of the skins. According to Swadling,

The entire bird is skinned in order to accentuate the beautiful plumes. During this process the legs, skull and coarse wing feathers are usually removed during skinning. Ash is applied to the inside of the skin and a stick is inserted through the mouth into the body cavity. The skin is then smoke dried. As the skin dries it collapses onto the stick which

28 Gilliard, Birds of paradise, p. 34.

29 Valentijn, Oud en nieuw, vol. 3, bk. 1, p. 311.

30 Wallace, Malay archipelago, p. 393.

31 D.H. Kolff, Voyages of the Dutch brig of war Dourga through the southern and little known parts of the Moluccan archipelago and along the previously unknown southern coast of New Guinea performed during the years 1825 \& 1826, trans. George Windsor Earl (London: James Madden \& Co., 1840), p. 210. 32 Alder, Isle of vanishing men, pp. 171-2. 
protrudes beyond the bill. Mounted in this way it is easy to incorporate the bird skin into a headdress. When not being worn the skins are usually stored in sealed bamboo tubes or palm leaf wrappings in the rafters so that fireplace smoke protects them from insects. ${ }^{33}$

These beautiful feathers were kept in these bamboo tubes for safekeeping and ease of transport when the feathers were needed for a festival. In this way the feathers were preserved for more than one occasion, hence obviating the need to replace the feathers every year and thus threatening the survival of the birds.

\section{The trade in birds of paradise}

While the trade in birds of paradise has a long history, the earliest firm evidence is from the Suma Oriental written in Melaka between 1512 and 1515 by the Portuguese apothecary, Tomé Pires. The Suma, a remarkably accurate compendium of information on trade in Asia, describes the arrival of an annual ship from the port of Cambay in northwest India bringing valuable cargo, among which were thirty types of cloth that were an essential item in the barter for Southeast Asian products. On the home journey it carried a variety of precious Southeast Asian goods, including birds of paradise whose plumes were greatly prized by the Turks and Arabs. ${ }^{34}$ The source of the birds was New Guinea, the Papuan islands of the Raja Ampat, and the Aru archipelago.

The most successful traders in Papuan goods, which included birds of paradise, were those from 'Southeast Seram', a general term used in this essay to refer to what the Dutch in the seventeenth and eighteenth centuries called 'East Seram'. It includes the easternmost corner of the island of Seram and its offshore islands, as well as the Seram Laut and Gorom archipelagoes. ${ }^{35}$ Despite the collective name, these Southeast Seram communities were independent entities and often in fierce competition with their neighbours, particularly in the trade with the Bird's Head Papuans. In resourcedeprived Southeast Seram there was a fierce rivalry for control over fishing reefs, and dyadic relationships were established with other communities to ensure access to food, other necessities, and trade goods. These Southeast Seramese settlements divided the coasts of the Bird's Head among themselves by establishing arrangements with the Papuans termed sosolot, which delineated the bays and anchorages that were considered their sole trading area. ${ }^{36}$

The tiny island of Kilwaru off the eastern tip of Seram was one of the islands frequently mentioned in the VOC accounts as an important trading site, and in the seventeenth century it sent some ten ships annually to Uring and Hote on the island of Seram to obtain Papuan goods from New Guinea. ${ }^{37}$ Kilwaru measured some 45

33 Swadling, Plumes, pp. 64-5.

34 The Suma Oriental of Tomé Pires, vol. 2, ed. Armando Cortesão (New Delhi: Asian Educational Services, 1990), p. 270.

35 Leonard Y. Andaya, The world of Maluku: Eastern Indonesia in the early modern period (Honolulu: University of Hawai'i Press, 1993), p. 56.

36 Roy Ellen, On the edge of the Banda zone (Honolulu: University of Hawai'i Press, 2003), p. 126; Thomas E. Goodman, 'The sosolot: An eighteenth century east Indonesian trade network' (Ph.D. diss. University of Hawai'i, Honolulu, 2006), p. 72.

37 Leonard Y. Andaya, 'Local trade networks in Maluku in the 16th, 17th, and 18th Centuries', Cakalele: Maluku Research Journal 2, 2 (1991): 84. 


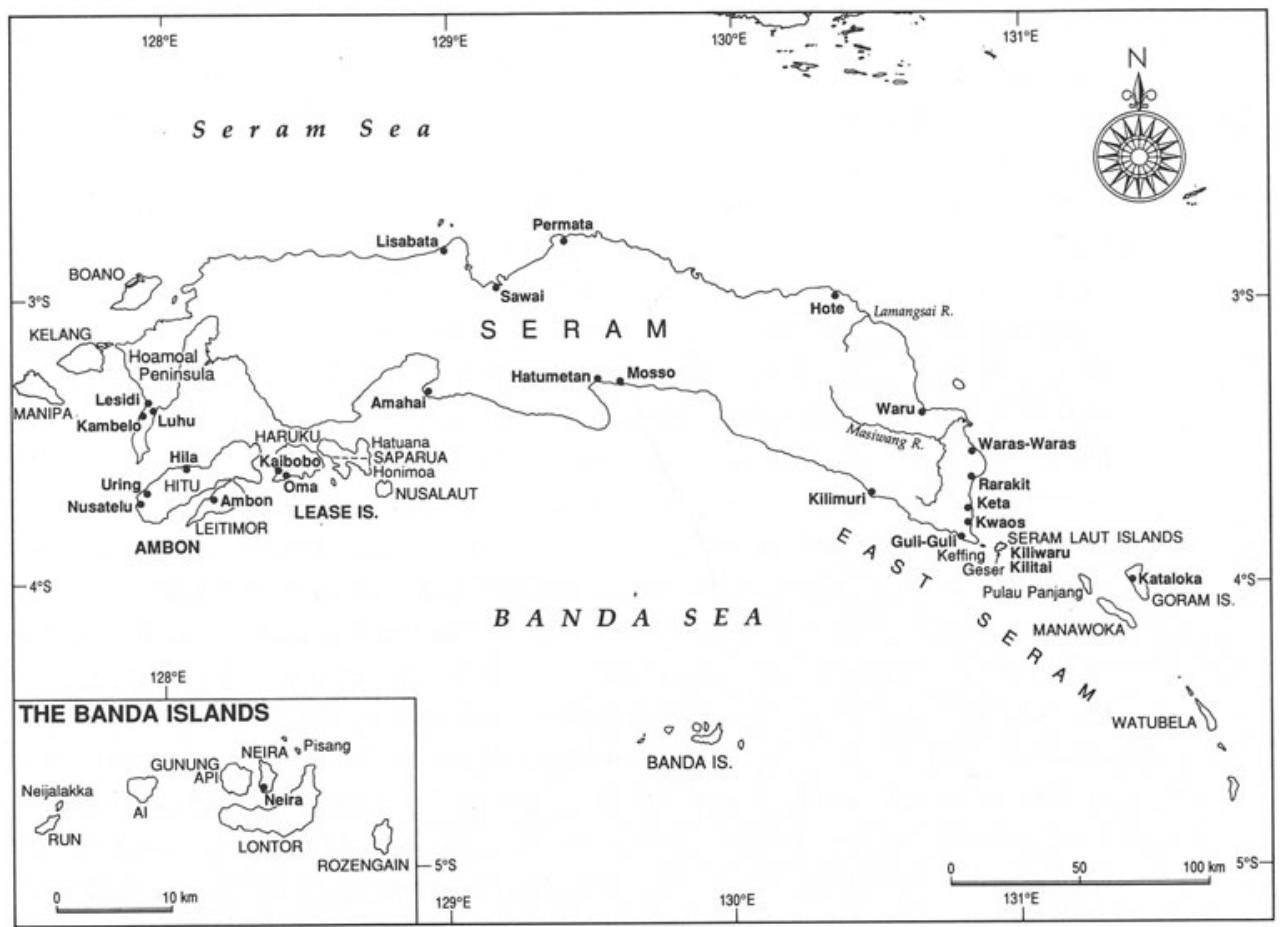

Map 3: East Seram

metres across and rose only a metre above sea level, but it had access to good ground water and safe anchorage in any monsoon weather. Those from Seram Laut and Gorom brought their goods from the Bird's Head to Kilwaru, where they were exchanged for cloth and sago, ${ }^{38}$ two essential items for the Papuan trade. Traders from all over the archipelago descended on Kilwaru, which provided a reliable market in eastern Indonesian products, such as spices, slaves, massoi bark, tortoiseshell, birds of paradise, and in the eighteenth century, trepang or sea cucumber.

The merchants of Southeast Seram divided the Bird's Head into three: Notan, Onin Lascar, and Onin Kowiai. Notan was prosperous and under the Raja of Waigeu, one of the Raja Ampat Islands. Sollewijn Gelpke, using the itinerary of Roxo de Brito (who was in the Raja Ampat Islands, the MacCluer Gulf in the Bird's Head Peninsula, and northern Seram from May 1581 to about November 1582), believes that Notan was located somewhere on the west coast of the island of Salawati. ${ }^{39}$ Goodman, however, has argued that Notan referred to the south and west coasts of the Bird's Head, 'a popular area for slave raiding and sago production'; Onin Lascar was to the northwest tip of the Onin Peninsula and later to an area from the southwest coasts of MacCluer Gulf to the Kumawa Peninsula, southeast of Fak Fak; and Onin Kowiai was originally to the coast from the Karas Islands east of

38 Swadling, Plumes, p. 142.

39 J.H.F. Sollewijn Gelpke, 'The report of Miguel Roxo de Brito of his voyage in 1581-1582 to the Raja Ampat, the MacCluer Gulf and Seram', Bijdragen tot de Taal-, Land-en Volkenkunde 150 (1994): 125-7. 
Fak Fak to Arguni Bay and later extended eastward to Etna Bay and even as far as the Omba River in the seventeenth and eighteenth centuries. ${ }^{40}$

Traders from the Gorom and Seram Laut archipelagoes, as well as those from Banda, purchased the birds of paradise from New Guinea, the Raja Ampat Islands, the Gamrange settlements, and Aru. In addition to collecting the birds from the sources of supply, they systematically visited each other's ports to purchase any which may have been brought there by the Papuan and Aru traders themselves. The Bandanese sailed with their larger boats directly to Aru for the birds, while their smaller boats were sent to the nearby Southeast Seram ports to seek further supplies. These traders from both Banda and Southeast Seram then sold their goods to other merchants from islands further west and to Batavia in exchange for iron and textiles, which were necessary to conduct trade with the Papuan and Aru collectors. ${ }^{41}$ Traders from the western part of the archipelago also came directly to the east to seek Papuan goods.

In 1632, for example, about twenty-eight boats were reported at one of the Seram Laut islands: eight were from the Malay lands, six from Makassar, and the remainder from Banten, Japara, and Bukit (east Java). ${ }^{42}$ Banda, and Makassar were major emporia and collecting points for eastern Indonesian goods, with the birds of paradise forming a part of this trade. ${ }^{43}$

The second important source of the trade in birds of paradise was the Tidore network based primarily in the Raja Ampat Islands, where their own species of the bird of paradise supplemented those from the New Guinea mainland. The coastal communities on the Bird's Head Peninsula had special trade arrangements with the small chiefdoms on the Raja Ampat Islands, which in turn were responsive to the heads of the Gamrange settlements of Maba, Weda, and Patani on the southeastern coast of Halmahera. The Gamrange then traded directly with the Tidorese traders, who were either based there or came annually to await the arrival of the Papuan products, including bird of paradise 'skins'. Tidore provided cloth, iron goods, and various small items to the Gamrange, who then issued these items as credit to the Papuans of the Raja Ampat Islands to barter for the birds of paradise from their trade friends in the Bird's Head Peninsula. Once the Raja Ampat Papuans returned home, their cargo was delivered to the Gamrange traders who had extended them credit. The latter then sold the birds of paradise directly to the Tidorese, who loaded the birds and other desired Papuan products on their kora-kora and sailed around the southern end of Halmahera, through the Patinti Straits, and finally northward to Tidore. ${ }^{44}$

The third major player in the trade in birds of paradise and other Papuan goods was the Chinese. They carved out a niche for themselves in the eastern Indonesian trading world and were among the most prominent traders to the coasts of the Bird's Head, acquiring massoi bark, slaves, tortoiseshell, bird of paradise plumes, etc., in exchange for cloth, porcelain, swords and knives. It was said that they even

40 Goodman, 'Sosolot', pp. 79-81; Sollewijn Gelpke, 'Report of Miguel Roxo de Brito': 130.

41 Ellen, Banda, pp. 86-7, 103-4.

42 Andaya, 'Local trade': 83-4.

43 M.A.P. Meilink-Roelofsz, Asian trade and European influence ('s-Gravenhage: Martinus Nijhoff, 1962), p. 95.

44 Andaya, 'Local trade': 72, 86-7. 
had wives in the interior to facilitate trade. In 1712 the VOC sought to disrupt the growing dominance of the Chinese traders by forbidding them from sailing east of Makassar. This measure was only partially successful because the Chinese quickly found ways to avoid the prohibition by becoming Muslim and obtaining the protection of a local sultan, or by clandestinely bringing the contraband goods to Bacan and the nearby uninhabited Obi Islands, where they were transferred to the waiting Chinese junks from Banda, Ambon, and Ternate. ${ }^{45}$

Another ban was instituted against the Chinese in 1731 because of the failure of the first, and again the Chinese were able to find ways to continue their successful trade in products from eastern Indonesia and New Guinea. A major factor in their favour was their willingness to extend credit to the collectors, which required both trust and patience since at times the collectors did not produce the promised goods, or the delivery could take many months. Instead of declining, the role of the Chinese increased and was helped considerably from the 1770s by an annual junk arriving in Makassar from Amoy (Xiamen). The junk was laden with Chinese products which were used by Chinese traders based in Makassar to obtain goods from the seas and forests of the archipelago for the return cargo to Amoy. ${ }^{46}$ The rise of Sulu in the last quarter of the eighteenth century provided yet another major port from which the Chinese junks could operate in the trade in eastern Indonesian and New Guinea products. ${ }^{47}$

A striking characteristic of the Chinese trade in the islands was the laborious process of obtaining small supplies from local traders until sufficient quantities of a product were collected. In one case it took a Chinese captain 43 months to gain a full boatload of goods. Unable to compete, the VOC instead sought to employ the Chinese in obtaining trade items on their behalf. ${ }^{48}$ There were others participating in this trade, but they were mainly secondary to the three major trade networks of Southeast Seram, Tidore/Raja Ampat Islands, and the Chinese. From Makassar the Papuan products, including the birds of paradise, found their way to China, while ports in the western half of the archipelago provided these desired items for the trade to India, the Middle East, and Europe.

Europeans who observed the manner in which the trade in birds of paradise occurred tended to view the exchange as an unequal one, with the Papuans being bought off with mere trinkets or objects of little value. It is important to stress, however, that the differing ideas of 'value' made it possible for both parties to be happy in the exchange. For example, the 'Tambuxe' swords were made at Tobunku in southeast Sulawesi and were highly prized among the Papuans and eastern Indonesian islanders, though Rumphius thought they were inferior to those made in Karimata. ${ }^{49}$

45 Ibid., 77.

46 Heather Sutherland, 'A Sino-Indonesian commodity chain: The trade in tortoiseshell in the late seventeenth and eighteenth centuries', in Chinese circulations: Capital, commodities, and networks in Southeast Asia, ed. Eric Tagliacozzo and Wen-chin Chang (Durham: Duke University Press, 2011), pp. 177, 179; Gerritt Knaap and Heather Sutherland, Monsoon traders: Ships, skippers, and commodities in eighteenth century Makassar (Leiden: KITLV, 2004), pp. 145-9.

47 Andaya, 'Local trade': 78.

48 Sutherland, 'Sino-Indonesian', p. 182.

49 Georgius Everhardus Rumphius, The Ambonese curiosity cabinet, trans. and ed. E.M. Beekman (New Haven: Yale University Press, 1999), p. 238. 
The more refined and valuable Indian textiles were often less in demand than the so-called 'ordinary cloth' mainly of cotton textiles from as far afield as India, but mainly from the islands of Java, Sumbawa (including Bima in the eastern part of the island), Sumba, and perhaps even Rote, Sabu, Timor, and other islands in Nusa Tenggara Timur (NTT, Eastern Lesser Sunda Islands) - all of which had weaving traditions. Ethnic Bugis, Makassarese, and Sama Bajau traders frequented these islands and would have been major carriers of such cloth to Southeast Seram, Tidore, or directly to the Bird's Head. ${ }^{50}$ In the Papuan areas, cloth was accumulated and came to play an important social and ritual role, where some were especially revered as 'kain timur', or eastern cloth. ${ }^{51}$

\section{Significance of bird of paradise plumage}

As mentioned, the attraction of the splendid bird of paradise plumes reached its peak in the early twentieth century, when feathered hats became the height of fashion in Europe and the Americas. Yet within a couple of decades the fashion had changed, and the demand for feathers declined. For the Europeans, the Turks, the Persians, and the Arabs, the feathers were a decorative ornament that provided an added glamour because of their exotic origin. But the feathers were also associated with authority and, in the Papuan areas, with the related concept of fertility. Among Papuans and some of the eastern Indonesian peoples, the feathers also conferred invulnerability to warriors who wore them to battle.

The earliest depictions of the feathered headdress in Southeast Asia are images found on the Dong Son drums. These bronze kettledrums have been found scattered from southern China to the coast of Papua, and their manufacture may have begun sometime between about 600 to $300 \mathrm{BCE}$ in the workshops of northern Vietnam. This period is known as the Dong Son phase of Vietnamese proto-history, and is characterised by the presence of bronze drums, high-status burials, and iron. Charles Higham argues that finished bronzes provided their owners with high social status (an opinion supported by Ian Glover ${ }^{52}$ ) and were displayed and thus rarely found in mortuary contexts. ${ }^{53}$ According to Amba Calò, between the late third to the fifth centuries CE some of these drums were carried from their production sites in northern Vietnam and southwest China to northern Borneo, Sulu, then to

50 Leonard Y. Andaya, 'Eastern Indonesia: A study of the intersection of global, regional and local networks in the "extended" Indian Ocean', in Reinterpreting Indian Ocean worlds: Essays in Honour of Kirti N. Chaudhuri, ed. Stefan C.A. Halikowski Smith (Cambridge: Cambridge Scholars, 2011), pp. 107-40; Lance Nolde, 'Changing tides: A history of power, trade, and transformation among the Sama Bajo sea peoples of eastern Indonesia in the early modern period' (Ph.D. diss., University of Hawai'i, Honolulu, 2015).

51 For a discussion of the role of 'kain timur', see Jaap Timmer, 'Cloths of civilisation: Kain timur in the Bird's Head of West Papua', Asia Pacific Journal of Anthropology 12, 4 (2011): 383-401; Moore, New Guinea, pp. 66, 70-72; Jelle Miedema, Pre-capitalism and cosmology: Description and analysis of the Meybrat fishery and kain timur-complex (Dordrecht: Foris, 1986).

52 Ian C. Glover, 'Bronze drums, urns, and bells in the early metal age of Southeast Asia', in Gods of Angkor: Bronzes from the National Museum of Cambodia, ed. Louise Allison Cort and Paul Jett (Washington, DC: Arthur M. Sackler Gallery, Smithsonian Institution, 2010), p. 19.

53 Charles Higham, Early cultures of mainland Southeast Asia (Bangkok: River Books, 2002), p. 175; Charles Higham, Archaeology of mainland Southeast Asia (Cambridge: Cambridge University Press, 1989), p. 187. 
the Sulawesi and Maluku seas. From these latter seas the drums entered into local trading systems, where their journey continued in the hands of local traders to the islands of eastern Indonesia and to Papua. The process continued and may have even extended to the Majapahit period (c.1293-1527), since Majapahit's links to eastern Indonesia are suggested by both a Javanese court text, the Desawarnana (1365), and by local NTT traditions. ${ }^{54}$

These bronze drums found in the islands of Sangeang, Salayar, Alor, Rote, central, southeast, and southwest Maluku, and northwest Papua have been categorised by Calò as 'Region Specific Cluster 3 (RS3)' because they shared a number of stylistic features. ${ }^{55}$ One of these features is the stylised feather patterns formed by the high feathered headdresses of the human figures depicted on the tympanum and the boat motifs on mantle panels, while the prow of the boat motifs appears to be a mythical birdnaga (cosmic snake). ${ }^{56}$ The association of bird feathers and authority, both sacral and secular, is implied in the decorative features of the RS3 drums. In her study of bird of paradise plumes, Pamela Swadling has proposed that these extraordinary and rare feathers were indicative of high status. ${ }^{57}$ It is a plausible idea and in keeping with Calò's interpretation. In 1772 M.P. Sonnerat reported that the Dutch supplied bird of paradise skins to the rich in Persia, Surat, and the East Indies, who used the plumes on their turbans, helmets, and horses. The same regard for this plumage was found in Nepal, where the ruler and principal ministers wore a ceremonial hat adorned with bird of paradise feathers for special occasions. ${ }^{58}$

When Magellan's crew reached Tidore in 1521, they were told that the people of Maluku wore bird of paradise feathers when going to battle because they believed that they were thus rendered invulnerable and invincible..$^{59}$ Valentijn confirms the practice of Muslim Malukans and Papuans in the seventeenth century going to battle wearing feathers in their helmets or headdresses. He also describes the displaying of these plumes on headdresses for festivals, where the warriors leap around and dance the cakalele with a spear or sword in hand in a mock-fight. A century later, Forrest also noted that the warriors tied a whole bird or parts of it to the back of their swords. For the people of Aru, Valentijn continued, only the very best feathers are used to adorn their helmets or headdress, but they do not perform the same type of dance as the Muslim Malukans and Papuans. ${ }^{60}$ When a BBC crew went to New Guinea to produce a documentary on the birds of paradise, they filmed special ceremonies where the Papuans wore elaborate headdresses containing feathers from a variety

54 Ambra Calò, The distribution of bronze drums in early Southeast Asia: Trade routes and cultural spheres (Oxford: Archaeopress, 2009), pp. 117-18; Hans Hägerdal, Lords of the land, lords of the sea: conflict and adaptation in early colonial Timor, 1600-1800 (Leiden: KITLV, 2012), p. 25; Syarifuddin R. Gomang, "The people of Alor and their alliances in Eastern Indonesia: A study of political sociology' (MA thesis, Wollongong University, 1993), pp. 30, 69, 87; Munandjar Widyatmika et al., Adat istiadat dan upacara perkawinan suku Dawan, Sumba dan Lamaholot, daerah Nusa Tenggara Timor (Kupang: Biro Penelitian Universitas Nusa Cendana, 1978), p. 19.

55 Calò, Distribution, pp. 111-17.

56 Ibid., p. 32.

57 Swadling, Plumes, pp. 53-5.

58 Ibid., p. 62.

59 Stresemann, 'Entdeckungsgeschichte': 263.

60 Valentijn, Oud en nieuw, vol. 1, bk. 3, p. 309; Forrest, Voyage, p. 137. 
of birds. The feathers were kept in sealed bamboo containers and stored in a dry place in the rafters of the house to be brought out when required for certain ceremonies. The film crew also were told that bird of paradise feathers formed part of a wedding settlement. ${ }^{61}$

The importance of the birds of paradise among the Papuans can be seen in the role that the birds play in their dances and festivals. In addition to having headdresses adorned with the plumage of various species of birds of paradise, the Papuans regard the birds as akin to themselves. ${ }^{62}$ As previously mentioned, the people even call the mating dance of the birds by the same name that is used for a war dance in Maluku, cakalele. One segment of the BBC documentary about the birds of paradise contains a shot of Papuan women dancing with an unusual movement of the head that imitates the mating dance of one species of the birds. A similar ceremonial dance among the Yonggom in New Guinea's west coast is described in vivid detail by Stuart Kirsch:

Dancers prepare for the yok dance by decorating their bodies with charcoal, red ochre, and white clay. Tied to the shoulders of the dancers are bundles of immature palm fronds that rise and fall with every step like the beating of wings. Tucked into their bark belts are seed rattles that mark their dance steps ... Wearing headdresses that feature plumes from the greater bird of paradise, Yonggom dancers mimic the movement of these birds in their display trees. The dancers' headdresses include a pair of white feathers from the sulfur-crested cockatoo, which move against one another like opposing metronomes. Like the male birds that congregate in display trees, the dancers seek to attract the amorous attentions of eligible females who have come to view their performance. The sublime beauty of the plumes and the rhythmic nature of the dance contribute to the desired effect of seduction. ${ }^{63}$

These Papuan ceremonies have a strong fertility symbolism - from the feathers used in the headdress to the movements of the dancers - and thus explains the importance of the bird of paradise feathers as an important part of any wedding settlement.

For the Papuans and some of the peoples of eastern Indonesia, bird of paradise feathers have continued to be valued because they fulfil a necessary role in society. Unlike elsewhere, where the feathers are equated with authority but mainly prized as ornamentation because of their brilliant colours and rarity, among the people in New Guinea and nearby islands, the birds of paradise are far more than that. They are regarded as guardians of the community, protecting warriors in battle and assuring the fertility of the womenfolk. The presence of the feathers in a household provides assurance to the family, while the ceremonies where the feathers are impressively displayed in headdresses, and where the dances conjure up the birds of paradise, are a celebration of the survival and prosperity of the entire community.

A head-hunting ceremony witnessed by an American explorer in the early 1920s among the Kia-Kia tribe near Port Moresby in New Guinea provides further evidence

61 Attenborough and BBC, Birds of paradise.

62 In Aru, Patsy Spyer has remarked on a similar equating of humans with the birds of paradise by the European observers of the late nineteenth century. Patricia Spyer, The memory of trade: Modernity's entanglements on an eastern Indonesian island (Durham: Duke University Press, 2000), p. 44.

63 Kirsch, 'History and the birds of paradise', 20. 
of this link between the feathers and fertility. In the ceremony, a group of old women waited until the singing of the participants reached a peak, then they entered into the houses and brought out trophy heads, which they had decorated with bird of paradise feathers for the occasion. These feathered heads were then given to the young women, who danced holding these heads and were joined later by the older women. The dance became frenzied with the women moving in a circular motion, swinging the heads and yelling out the exploits of their ancestor warriors while berating the men for being lazy and incapable of bringing meat for the family. They swung the feathered heads wildly while screeching and threatening to withhold sexual favours from the men. Their cajolery and enticements, accompanied by increasingly frenetic dancing, aroused the men to join in until all were part of a seething mass of bodies. The old women then returned to the houses to fetch the weapons for the men going on a head-hunting expedition. A noteworthy feature of this head-hunting ceremony was the placing of bird of paradise feathers on the trophy heads, thus combining two powerful symbols of fertility. ${ }^{64}$

\section{Conclusion}

The extraordinary beauty of its plumage and the mystery surrounding its habits made the bird of paradise a coveted item in international trade. Through an interlocking trading network of collectors, intermediaries, and ports stretching from New Guinea to major world centres, the brilliant feathers came to be worn by the rich and powerful in Europe, the Middle East, India, and China. The association of feathers with elite status and authority has an ancient pedigree dating back to the prehistoric Dong Son drums and their feathered complex of human figures and boats. While the feathers of the bird of paradise were prized for this reason, in the early twentieth century they also come to fulfil the more mundane but popular role as exotic ornaments on the hats of fashionable women in the West. Yet the greatest reverence for this 'bird of God' is exhibited by the Papuans living in close proximity to the bird's natural habitat. In special ceremonies, the plumage of the bird of paradise is worn by dancers in order to invoke the special powers of this 'bird of God' to safeguard and assure the fertility of the land and its people.

Many historians have tended to view trade purely as an economic venture, but there are other important consequences of such exchanges that often go unnoticed or unmentioned. As this essay has shown, trade has been the means by which small, peripheral communities with just one commodity of interest have become linked to a global network and hence to outside ideas. This is as true of the past as it is today. An equally fruitful way of thinking about trade is its cultural impact not only on the receiving society but also on the producers or collectors themselves. Through the magnificence of their plumage and their stunning mating dance, the birds of paradise have continued to fascinate the world. For this reason, there has been a variety of attitudes attached to these birds, offering cultural insights that go well beyond simply the economics of exchange of material goods.

64 Alder, Isle of vanishing men, pp. 150-52. There is a rich literature on the association of headhunting and fertility. For an enlightening discussion on this subject, see Barbara Watson Andaya, 'History, headhunting and gender in monsoon Asia: Comparative and longitudinal views', South East Research 12, 1 (2004): 13-52. 